\title{
Interactive comment on "A hydrodynamic model for Galveston Bay and the shelf in the northwestern Gulf of Mexico” by Jiabi Du et al.
}

Jiabi Du et al.

jdu@tamug.edu

Received and published: 17 April 2019

Thanks very much for the helpful comments. Responses to the comments can be found in the attached file.

Please also note the supplement to this comment:

https://www.ocean-sci-discuss.net/os-2019-9/os-2019-9-AC2-supplement.pdf

Interactive comment on Ocean Sci. Discuss., https://doi.org/10.5194/os-2019-9, 2019. 